\title{
Strategies to Interpret Javanese Cultural Terms Made by Tourist Guides at Kasunanan Palace of Surakarta
}

\author{
Budi Purnomo* \\ Sahid Tourism Institute of Surakarta, Indonesia \\ Email: budipurnomo989@yahoo.co.id
}

\begin{abstract}
This study attempts to investigate the strategies to interpret Javanese cultural terms used by tourist guides at Kasunanan Palace of Surakarta. The study is intended to be a descriptive and qualitative nature. The data were collected by joining ten guided group tours in Kasunanan Palace and recording the tourist guides' interpretation of Javanese cultural terms to tourists. To know the types of interpretation strategies, the Javanese cultural terms and their English interpretation were analyzed by Newmark's strategies for dealing with a cultural gap (1998a). The research findings show that the strategies used by the tourist guides to interpret Javanese cultural terms from the most to the least are: (1) descriptive and functional equivalent, (2) cultural equivalent, (3) naturalization, (4) neutralization and (5) compensation. The findings imply that the interpretation strategies used by the tourist guides are essential to obtain interpretation products that have equivalence to the Javanese cultural terms to be preserved in this millennial era.
\end{abstract}

Keywords: interpretation strategies, tourist guides, Javanese cultural terms

\section{A. INTRODUCTION}

Every country has its own culture as a character or a way of life. This character has to be preserved and maintained by every citizen of a country including Indonesia as a big nation which has many cultures and tribes. One of the efforts to preserve cultures is spreading information of them to people outside the country using English as an international language (Suryaningsih \& Mardiana, 2017). It can be started by Indonesian tourist guides to interpret cultural terms during providing assistance and information to English speaking tourists visiting tourist destinations. It is in line with the duties of a tourist guide as stated by the World Federation of Tourist Guide Associations (2013):

A tourist guide is a person who guides visitors in the language of their choice and interprets the cultural and natural heritage of an area which person normally possesses an area-specific qualification usually issued and/or recognised by the appropriate authority.

As a historical tourist destination located at Central Java Province, Kasunanan Palace of Surakarta was built in 1745 by King Pakubuwono II. This three-century age palace is necessary to be preserved both the building and its culture in order that this invaluable cultural heritage can be passed down from one generation to the next. The culture still used today in this palace environment is Javanese culture that is rich in specific terminology. Javanese cultural terms are the linguistics units which are very specific to Javanese culture and society. Nirmala (2015) stated that Javanese cultural words represent festivals, rituals, Javanese ways of life, social activities, actions, feelings, thoughts, behavior, and experiences.

The Javanese cultural terms is included in the traditional cultural expressions (TCEs). The TCEs may include music, dance, art, designs, names, signs and symbols, performances, ceremonies, architectural forms, handicrafts and narratives, or many other artistic or cultural expressions (World Intellectual 
Property Organization, 2019). The TCEs may be considered as the forms in which traditional culture is expressed; form part of the identity and heritage of a traditional or indigenous community; and are passed down from generation to generation. TCEs are integral to the cultural and social identities of indigenous and local communities, embody know-how and skills, and transmit core values and beliefs. Their protection is related to the promotion of creativity, enhanced cultural diversity and the preservation of cultural heritage.

The Javanese cultural terms are somehow difficult to interpret, even professional tourist guides find them difficult to deal with. It is because the cultural context is too vague, it represents the world view of Javanese society, its beliefs, emotions and values. Chahrour (2018) stated that though some cultural concepts seem to be universal, however they are not interpreted in the same way; each language has its own interpretation according to its people's way of thinking, living style, and even their geographic position. Magablih et.al (2010) suggested tourist guides to use different interpretation strategies to explain a variety of cultural terms in Jordan to foreign tourists. These strategies vary from one guide to another in many cases. This relates mainly to the difficulty of translating such cultural elements to tourists who are usually unfamiliar with such terms. In addition, Purnomo (2017) advised to tourist guides that to interpret cultural terms, addition, borrowing, synonymy, descriptive equivalent and componential analysis are good strategies to use.

Related to interpreting cultural terms, Newmark (1998a) introduced some strategies for dealing with the cultural gap: (1) naturalization. A strategy when a SL word is transferred into TL text in its original form; (2) couplet or triplet and quadruplet. Is another technique the translator adopts at the time of transferring, naturalizing or calques to avoid any misunderstanding? According to him, it is a number of strategies combine together to handle one problem; (3) neutralization. It is a kind of paraphrase at the level of the word. If it is at a higher level it would be a paraphrase. When the SL item is generalized (neutralized) it is paraphrased with some culture free words; (4) descriptive and functional equivalent. In explanation of source language cultural item, there are two elements: one is descriptive and another one would be functional. Descriptive equivalent talks about size, color, and composition. The functional equivalent talks about the purpose of the SL cultural-specific word; (5) an explanation as the footnote. The translator may wish to give extra information to the TL reader. He would explain this extra information in a footnote. It may come at the bottom of the page, at the end of the chapter or at the end of the book; (6) cultural equivalent. The SL cultural word is translated by TL cultural word; and (7) compensation. A technique which is used when confronting a loss or meaning, sound effect, pragmatic effect or metaphor in one part of a text. The word or concept is compensated in other parts of the text.

The main aim of this paper is to investigate the strategies as suggested by Newmark (1998a) used by local tourist guides to interpret Javanese cultural terms during providing assistance and information to English speaking tourists visiting Kasunanan Palace of Surakarta.

\section{B. RESEARCH METHOD}

This qualitative and descriptive research was done at Kasunanan Palace of Surakarta which is not only a home to the king and his family, but also become the flame guard of Javanese culture. In this palace the tourists can learn from seeing directly on how culture still being preserved in the pace development of the world. The data were collected through joining ten guided group tours in the palace and recording the tourist guides' interpretation of Javanese cultural terms to English speaking tourists. The structure of tour participants includes people from all walks of life, of different levels of education and of ages. The guided group tours formed the arena where expressions of interaction between tourist guides and tourists could be observed. 
The Javanese cultural terms were classified into five categories: palace properties, royal heirlooms, ancient weapons, precious antiques and cultural ceremonies (Purnomo, 2017). These categories are the main components of the cultural heritage promoted by the Ministry of Tourism to be continuously preserved. The collected data were categorized in terms of the strategies used in interpreting Javanese cultural terms. The data were in the forms of tourist guides' expressions that contain 100 Javanese cultural terms along with their interpretations.

\section{RESULTS AND ANALYSIS}

Many Javanese cultural terms should be interpreted into English by the tourist guides during their interaction with the tourists at Kasunanan Palace of Surakarta. There are five types of interpretation strategies used by the Indonesian tourist guides to interpret the cultural terms: descriptive and functional equivalent, cultural equivalent, naturalization, neutralization and compensation.

\section{Descriptive and functional equivalent}

Descriptive equivalent strategy is used to interpret a source language using a description of the concept that refers to the target language. Functional equivalent means using a referent in the TL culture whose function is similar to that of the SL referent.

The following is an example of descriptive equivalent strategy used by a tourist guide.

Tourist : Where are we, now?

Guide : We are passing the main gate, Kori Brojonolo. Literally, brojo means sharp weapon, and nolo means heart. Entering brojonolo, we should have the sharpness of heart or in Javanese 'landeping rasa'.

In the above conversation, the tour guide tried to describe meaning and function of words brojo and nolo in Javanese because the words are very closely related to specific culture in the source language and the use of cultural equivalence did not give accuracy needed.

\section{Cultural equivalent}

Cultural equivalent strategy means replacing a cultural word in the SL with a TL one. The following is an example of cultural equivalent strategy used by a tourist guide.

Tourist : Who is standing in front of the entrance gate?

Guide : He is a palace staff or abdi dalem in Javanese. Abdi means staff and dalem means palace.

In the above conversation, the tour guide used the phrase palace staff to interpret abdi dalem. So, the phrase palace staff can be easily understood by the tourists.

\section{Naturalization}

Naturalization means adapting the SL word first to the normal pronunciation, then to the normal morphology of the TL. The following is an example of naturalization strategy used by a tourist guide.

Tourist : What building is that?

Guide : It's gandhok bambu, a formerly bamboo room where the king family live.

In the above conversation, the tour guide used the word bamboo in English, an adaptation of the original word bambu in Javanese (naturalization strategy).

\section{Neutralization}


Neutralization applied when a tourist guide has a concept from a source culture that does not exist in the target culture and therefore s/he needs to explain the meaning in order to make the word understandable to the tourists.

The following is an example of neutralization strategy used by a tourist guide.

Tourist : What are the street vendors selling on the road to Panggung Songgobuwono?

Guide : That's wedang dongo, the Solo's special hot drink which comprises ginger syrup with bright sticky rice flour shaped into balls, roasted peanuts and sugar palm fruit. The other is sego liwet, a rice dish cooked in coconut milk, chicken broth and spices, served with shredded chicken and other side dishes.

In the above conversation, the terms wedang dongo and sego liwet did not exist in the English culture and therefore the tourist guide explained the meaning in English in order to make the terms understable to the tourists.

\section{Compensation}

Compensation occurs when loss of meaning in one part of a sentence is compensated in another part. The following is an example of compensation strategy used by a tourist guide.

Tourist : A lot of yellow coconut leaf here, what for?

Guide : They're used for Adeging Nagari Surakarta Hadiningrat ...to commemorate Surakarta City's 274th anniversary.

In the above conversation, the terms Adeging Nagari Surakarta Hadiningrat was not interpreted into English, but compensated in English terms to commemorate Surakarta City's 274th anniversary.

Based on the data analysis above, frequency of strategies used by the tourist guides to interpret Javanese cultural terms can be summarized by Table 1.

Table 1. Types of Javanese cultural terms and of interpretation strategies

\begin{tabular}{lccrrc}
\hline \multirow{2}{*}{ Strategy } & \multicolumn{1}{c}{ Javanese } & Cultural & Terms & \\
\cline { 2 - 6 } & $\begin{array}{l}\text { Palace } \\
\text { properties }\end{array}$ & $\begin{array}{l}\text { Royal } \\
\text { heirlooms }\end{array}$ & $\begin{array}{l}\text { Ancient } \\
\text { weapons }\end{array}$ & $\begin{array}{l}\text { Precious } \\
\text { antiques }\end{array}$ & $\begin{array}{l}\text { Cultural } \\
\text { ceremonies }\end{array}$ \\
\hline $\begin{array}{l}\text { Descriptive \& } \\
\text { functional } \\
\text { equivalent }\end{array}$ & $11(55 \%)$ & $8(40 \%)$ & $9(45 \%)$ & $\begin{array}{r}10 \\
(50 \%)\end{array}$ & $7(35 \%)$ \\
\hline $\begin{array}{l}\text { Cultural } \\
\text { equivalent }\end{array}$ & $5(25 \%)$ & $6(30 \%)$ & $7(35 \%)$ & $3(15 \%)$ & $5(25 \%)$ \\
\hline Naturalization & $2(10 \%)$ & $3(15 \%)$ & $1(5 \%)$ & $3(15 \%)$ & $4(20 \%)$ \\
\hline Neutralization & $1(5 \%)$ & $2(10 \%)$ & $1(5 \%)$ & $3(15 \%)$ & $2(10 \%)$ \\
\hline Compensation & $1(5 \%)$ & $1(5 \%)$ & $1(5 \%)$ & 1 & $2(10 \%)$ \\
\multicolumn{1}{c}{ Total } & $20(100 \%)$ & $20(100 \%)$ & $\begin{array}{r}20 \\
(5 \%)\end{array}$ & 20 \\
\hline
\end{tabular}

From the above table, it can be seen that from 100 samples of data analysis towards the Javanese cultural terms of palace properties, royal herlooms, ancient weapons, precious antiques and cultural ceremonies at Kasunanan Palace of Surakarta, it has gotten 55\% of descriptive and fuctional equivalent strategy in palace properties, $40 \%$ in royal heirlooms, $45 \%$ in ancient weapons, $50 \%$ in precious antiques and $35 \%$ in cultural ceremonies. Next, it has gotten $25 \%$ of cultural equivalent strategy in palace properties, $30 \%$ in royal heirlooms, $35 \%$ in actient weapons, $15 \%$ in precious antiques and $25 \%$ in cultural ceremonies. After that, it has gotten $10 \%$ of naturalization strategy in palace properties, $15 \%$ in royal 
heirlooms, $5 \%$ in ancient weapons, $15 \%$ in precious antiques and $20 \%$ in cultural ceremonies. Then, it has gotten $5 \%$ of neutralization strategy in palace properties, $10 \%$ in royal heirlooms, $5 \%$ in ancient weapons, $15 \%$ in precious antiques and $10 \%$ in cultural ceremonies. The last, it has gotten $5 \%$ of compensation strategy in palace properties, $5 \%$ in royal heirlooms, $5 \%$ in ancient weapons, $5 \%$ in precious antiques and $10 \%$ in cultural ceremonies. So, it can be inferred that the most dominant interpretation strategy used by tourist guides at Kasunanan Palace of Surakarta is descriptive and functional equivalent. On the other hand, the least dominant strategy used by the tourist guides is compensation.

\section{CONCLUSION}

This research has been able to fulfil the research objectives articulated in the introduction section. The first objective relates to the types of Javanese cultural terms should be interpreted into English by the tourist guides during their interaction with the tourists. The data analysis has indicated that the types of Javanese cultural terms include palace properties, royal heirlooms, ancient weapons, precious antiques and cultural ceremonies.

The second objective relates to the types of strategies used to interpret Javanese cultural terms into English. The data analysis has indicated that the interpretation strategies used from the most to the least are descriptive and functional equivalent, cultural equivalent, naturalization, neutralization and compensation.

The findings indicate strongly that since interpretation strategies are essential to obtain interpretation products that have equivalence to the Javanese cultural terms as a local wisdom should be preserved in this Industry 4.0 Era, the tourist guides at Kasunanan Palance of Surakarta should improve their interpretation competences in order to fulfil the tourists' needs.

\section{ACKNOWLEDGMENTS}

Many thanks to Kanjeng Pangeran Aryo Winarno Kusumo (deceased), the Deputy of Pengageng Sasana Wilapa of Kasunanan Palace of Surakarta who gave valuable suggestions during the data collection for this research.

\section{REFERENCES}

Chahrour, O. (2018). Cultural problems in translation. Translation Journal, 7 (2), 13-125.

Magablih, K., Abdulhaiha, L.A. \& Saleh, M.A. (2010). Interpretation strategies used by Jordanian tourist guides to handle cultural specificity in tourism material. TEAM Journal of Hospitality and Tourism, 7(1), 1-12.

Newmark, P. (1998a). A Textbook of Translation. Hertfordshire: Prentice Hall.

Nirmala, D. (2015). Javanese cultural words in local newspapers in Central Java as a language maintenance model. Humaniora, 27 (3), 293-300.

Purnomo, B. (2017). "More than words: Strategies used by Indonesian tourist guides to interpret cultural terms in Surakarta and Yogyakarta Royal Palaces." in 1st English Language and Literature International Conference (ELLic). Semarang: Muhammadiyah University of Semarang.

Suryaningsih, R.A. S. \& Mardiana, R. (2017). Indonesian text about Javanese culture into English text: Most common translation strategies on the perpective on Vinay \& Darbelnet (A case study of vocational students of Bogor Agricultural University). International Journal of Linguistics, Language and Culture (IJLLC), 3 (3), 1-9.

World Federation of Tourist Guide Associations (2013). Definition of Tourist Guide. http://www.wftga.org/tourist-guiding/what-tourist-guide, 2 May 2019.

World Intellectual Property Organization (2019). Traditional Cultural Expressions. https://www.wipo.int/tk/en/folklore/, 5 May 2019. 


\section{Halaman ini sengaja dikosongkan}

96 | Barista: Jurnal Kajian Bahasa dan Pariwisata, Volume 7 Nomor 2, 2020: 91-96 